УДК 338.436 .33

Н. В. Медяник

ФГАОУ ВО «Северо-Кавказский федеральный университет»,

Пятигорский институт (филиал) СКФУ, Пятигорск,

e-mail: natalya-medyanik@yandex.ru

О. А. Чередниченко

ФГБОУ ВО «Ставропольский государственный аграрный университет»,

Ставрополь, e-mail: chered72@mail.ru.

Н. А. Довготько

ФГБОУ ВО «Ставропольский государственный аграрный университет»,

Ставрополь, e-mail: ndovgotko@yandex.ru

ФОРМИРОВАНИЕ СБАЛАНСИРОВАННОЙ

СИСТЕМЫ ИНДИКАТОРОВ ДЛЯ ОЦЕНКИ

СТЕПЕНИ ДОСТИЖЕНИЯ ЦЕЛЕЙ УСТОЙЧИВОГО РАЗВИТИЯ

В НАЦИОНАЛЬНОЙ АГРОПРОДОВОЛЬСТВЕННОЙ СИСТЕМЕ

Ключевые слова: устойчивое развитие, агропродовольственная система, сбалансированная система показателей, индикаторы целей устойчивого развития.

В рамках методологического ключа, основанного на принципах устойчивости ФАО и авторского подхода к устойчивости национальной агропродовольственной системы, методических разработках и оценочном инструментарии статистических подразделений ООН, ФАО, Росстата, предпринято обоснование сбалансированной системы индикаторов для оценки степени достижения целей устойчивого развития национальной агропродовольственной системы, основанной на совокупности систематически мониторируемых и статистически верифицируемых количественных индикаторов в разрезе сельского хозяйства, смежных с ним отраслей, сельских населения и территорий. Предложено показатели социальной компоненты (ЦУР $1,2,3,4,5,16)$ связать с сокращением сельской бедности и неравенства, обеспечением сельского населения продовольствием и социальной инфраструктурой, условиями для сельского развития, параметрами здоровья сельского населения и качества медицинских услуг, доступностью многоуровневого образования; экономической компоненты (ЦУР 8,9,10,12,17) с развитием аграрной экономики, продовольственным обеспечением, сельской занятостью, инфраструктурой сельских территорий, агро- индустриализацией и инновациям, переходом к рациональным моделям потребления и производства, включенностью национального аграрного сектора в мирохозяйственные связи; экологической компоненты (ЦУР 6,7,11,13,14,15) со сбережением и обеспеченностью водой, энергией сельской местности и аграрной отрасли, адаптацией сельского хозяйства к климатическим и природным рискам, репродукцией, долговременной продуктивностью, рациональным использованием природных ресурсов в агарном производстве и качеством среды в сельской местности. Подобная оценочная система позволяет количественно тестировать специфику и факторы аграрной экономики, масштабы ее воздействия на экологические системы, уровень социального благополучия сельских населения и территорий, служить адекватным национальной проблематике и глобальным тенденциям ориентиром, индикатором результативности и эффективности управленческих и бизнес решений в контексте устойчивости национальных агропродовольственных систем.

N. V. Medyanik

North-Caucasian Federal University, branch in Pyatigorsk, Pyatigorsk, e-mail: natalya-medyanik@yandex.ru

\title{
O. A. Cherednichenko
}

Stavropol state agrarian university, Stavropol, e-mail: chered72@mail.ru

N. A. Dovgotko

Stavropol state agrarian university, Stavropol, e-mail: ndovgotko@yandex.ru

FORMATION OF A BALANCED SYSTEM OF INDICATORS

TO ASSESS THE DEGREE OF ACHIEVEMENT OF SUSTAINABLE DEVELOPMENT GOALS IN THE NATIONAL AGRI-FOOD SYSTEM

Keywords: sustainable development, agri-food system, balanced scorecard, indicators of sustainable development goals. 
Within the framework of the methodological key based on the principles of FAO sustainability and the author's approach to the sustainability of the national agro-food system, methodological developments and evaluation tools of the statistical units of the United Nations, FAO, Rosstat, the rationale for a balanced system of indicators to assess the degree of achievement of the sustainable development goals of the national agro-food system, based on a set of systematically monitored and statistically verified quantitative indicators in the context of agriculture, related industries, has been undertaken, rural population and territories. It is proposed to link the indicators of the social component (SDG 1,2,3,4,5,16) with the reduction of rural poverty and inequality, provision of rural population with food and social infrastructure, conditions for rural development, health parameters of rural population and quality of medical services, accessibility of multilevel education; economic (SDG 8,9,10,12,17) with the development of the agrarian economy, food security, rural employment, rural infrastructure, agro-industrialization and innovation, the transition to rational models of consumption and production, the inclusion of the national agricultural sector in world economic relations; environmental (SDG 6,7,11,13,14,15) with conservation and provision of water, energy in rural areas and the agricultural sector, adaptation of agriculture to climatic and natural risks, reproduction, long-term productivity, rational use of natural resources in agar production and environmental quality in rural areas. Such an assessment system makes it possible to quantitatively test the specifics and factors of the agrarian economy, the extent of its impact on environmental systems, the level of social well-being of rural populations and territories, serve as a guideline adequate to national issues and global trends, an indicator of the effectiveness and efficiency of management and business decisions in the context of the sustainability of national agro-food systems.

\section{Введение}

Как известно, в 2015 году Генассамблеей $\mathrm{OOH}$ на смену Целям развития на пороге тысячелетия ООН (Millennium Development Goals, ЦРТ) были приняты 17 Целей устойчивого развития на период до 2030 года (Sustainable Development Goals, ЦУР-2030), обеспечивающие всеохватный, поступательный экономический рост, социальное благополучие, охрану окружающей природной среды, иными словами - сбалансированность традиционной триады устойчивого развития [1].

Вполне справедливо, что идеология устойчивого развития все более становится имманентным атрибутом развития агропродовольственных систем (АПС). Глубокое понимание подобного подхода демонстрирует $Ф А О$, оказывая национальным правительствам поддержку в создании «инклюзивных (интегрирующих устойчивость в трех ее измерениях: социальном, экономическом и экологическом - прим. авторов), эффективных и устойчивых продовольственных систем, способных к 2050 году обеспечить полноценным продовольствием почти 10 млрд. населения Земли, достойную занятость и доходы всем участникам производственно-сбытовой аграрной цепи, привлекательность сельского образа жизни, и делать это без ущерба для природных ресурсов $[2,3]$.

Не случайно, среди 17-ти сформулированных ООН глобальных целевых ориентиров до 2030 года, по крайне мере, одна ЦУР 2 связана с содействием устойчивому развитию сельского хозяйства и обеспечением продовольственной безопасности [1].
Между тем успех реализации целей в области устойчивого развития зависит в значительной степени от релевантности целеполаганию аналитических показателей, качества статистической информации и оценочных процедур.

Концептуальному и методическому решению данной проблемы посвящены разработки зарубежных ученых G. Fischer, N. Siebrecht, M. Lampridi, C. Sørensen, D. Bochtis, R. Valentini, J. Sievenpiper, C. Allen, G. Metternicht, T. Wiedmann $[4,5,6,7,8]$. Прикладной оценочный инструментарий содержится в ряде работ В.М. Белоусова, В.И. Нечаева, Е.В. Емельяновой, Н.Ю. Пастуховой, Н.А. Довготько, О.А. Чередниченко, Н.Н. Яшаловой $[9,10,11,12]$.

Между тем, не смотря на инициированные с 1992 года Конференции ООН по устойчивому развитию научные разработки и накопленный значительный аналитический опыт, следует указать на отсутствие не только в РФ, но и в мире единой методики и перечня показателей устойчивого развития применительно к АПС.

Так, сформированная структурами $\mathrm{OOH}$ методическая платформа и оценочный инструментарий в большей степени ориентированы на глобальный уровень ЦУР $[13,14,15$, $16,17,18]$, полагая, что вполне справедливо, существенной редакции и адаптации к национальной специфике функционирования АПС.

Не многочисленные отечественные разработки в оценке устойчивого развития аграрного сектора экономики, имея в виду сложный и многогранный характер подобного феномена, требуют методического уточнения и дальнейшей системной про- 
работки. Не менее важным остается вопрос статистической верификации и наличия регулярной информационной базы в системе государственной статистики.

Цель исследования заключается в систематизации и критическом анализа методических подходов ООН и оценочных процедур в достижении ЦУР-2030, максимальной их адаптации к информационностатистическим реалиям России и параметрам устойчивого развития национальной агропродовольственной системы.

\section{Материалы и методы исследования}

В рамках методологического ключа, основанного на принципах ФАО и авторского подхода к устойчивости национальной АПС, с использованием методических разработок и оценочного инструментария ФАО, Статистической комиссии $\mathrm{OOH}$, Статистического отдела $\mathrm{OOH}$, Федеральной службы государственной статистики РФ в реализации Повестки дня в области устойчивого развития на период до 2030 года предпринята попытка обоснования сбалансированной системы индикаторов для оценки степени достижения ЦУР национальной АПС.

\section{Результаты исследования и их обсуждение}

Как было отмечено, выше в Повестке дня в области устойчивого развития на период до 2030 года агропродовольственным системам отводится если не ключевая, то весьма существенная роль в реализации ряда критически важных для общества целей и задач. Среди них, не только ЦУР 2, но и содействие здоровью населения (ЦУР 3), гендерному равенству и обеспечению доступности женщин к сельскохозяйственным факторам (ЦУР 5), рационализация использования водных (ЦУР 6), морских (ЦУР 14), наземных экосистем, биологических, земельных (ЦУР 15) ресурсов, моделей производства и потребления (ЦУР 12), обеспечение поступательного роста, производительного труда, достойной занятости (ЦУР 8) и внедрение инноваций (ЦУР 9), прежде всего, климатически адаптированных (ЦУР 13) в аграрном производстве, благоустройство и комфортное жизнеобеспечение сельских поселений (ЦУР 11).

Между тем на практике достижение обозначенных ЦУР 2030 во многом зависит от обеспечения устойчивости собственно АПС, «полагая в долгосрочном периоде экономически эффективное производство необходимого для каждого человека количества и качества продуктов питания, целостность используемых в аграрном производстве экосистем, а также социально-экономическое благополучие сельских жителей и территорий» [19].

Подобный подход, по всецело поддерживаемой нами версии ФАО, воплощают пять базовых, принципов устойчивости АПС, обеспечивающих сбалансированность экономических, экологических и социальных аспектов ведения аграрного производства и сельского образа жизни, а именно:

- первый принцип - повышение производительности, занятости и добавленной стоимости в продовольственных системах, справедливо сопряженный с повышением эффективности использования экономических ресурсов в аграрном производстве;

- второй принцип - защита и приумножение природных ресурсов, как материального базиса функционирования АПС;

- третий принцип - улучшение условий жизни и содействие инклюзивному экономическому росту, что, отражая социальный аспект устойчивости АПС, связан с обустройством сельских территорий, социальным благополучием сельских жителей;

- четвёртый принцип - повышение устойчивости людей, сообществ и экосистем, прежде всего, к стихийным бедствиям природного характера, обусловленным климатическими изменениями и погодными стрессам;

- пятый принцип - адаптированность управления к новым вызовам, иначе разработка и реализация управленческих решений, обеспечивающих устойчивые модели ведения сельского хозяйства и производства продовольствия [15, 16, 19].

В контексте аналитической проблематики реализация подобного методического подхода позволяет не только обеспечить УР АПС, реализацию к 2030 году отмеченных выше ключевых целей и задач, равно разработать сбалансированную систему индикаторов для оценки степени их достижения, более того выработать оценочный инструментарий для комплексной диагностики параметров устойчивости агропродовольственной системы, в том числе с учетом национальной специфики.

Попыткой разработки подобной сбалансированной системы оценочных показателей ЦУР в контексте функционирования национальной АПС авторами предпринята систематизация методического, оценочного, информационно-статистического инструментария, результаты которой представлены в таблице 1. 
Параметры сбалансированной системы индикаторов для оценки степени достижения ЦУР АПС (по версии ФАО) [3, 20]

\begin{tabular}{|c|c|c|c|c|c|c|}
\hline \multicolumn{2}{|c|}{ Принципы УР 1} & \multirow{2}{*}{\begin{tabular}{|l|} 
Принцип 1 \\
1.4
\end{tabular}} & \multirow{2}{*}{\begin{tabular}{|l|} 
Принцип 2 \\
1.4
\end{tabular}} & \multirow{2}{*}{\begin{tabular}{c|} 
Принцип 3 \\
$1.1,1.2,1.3,1.4,1.5$
\end{tabular}} & \multirow{2}{*}{$\frac{\text { Принцип } 4}{1.5}$} & \multirow{2}{*}{\begin{tabular}{|l|} 
Принцип 5 \\
$1 \mathrm{a}, 1 \mathrm{~b}$
\end{tabular}} \\
\hline \multirow[t]{3}{*}{ ЦУР ${ }^{2} 1$} & Задачи ${ }^{2}$ & & & & & \\
\hline & $\Phi \Phi^{3}$ & \multicolumn{5}{|c|}{ 1.4.2,1.5.2 (доп) } \\
\hline & $\begin{array}{l}\text { Poc- } \\
\text { стат }^{3}\end{array}$ & \multicolumn{5}{|c|}{$\begin{array}{l}\text { 1.2.1, Индекс риска бедности и социальной исключенности (AROPE) (1.2), Доля рас- } \\
\text { ходов на социальную поддержку граждан к собственным доходам консолидированных } \\
\text { бюджетов субъектов РФ (1.3) }\end{array}$} \\
\hline \multirow[t]{3}{*}{ ЦУР 2} & Задачи & $2.1,2.2,2.3,2.4$ & $2.4,2.5$ & $2.1,2.2,2.3,2.4$ & 2.4 & $2.1,2.3,2.4,2 \mathrm{a}$ \\
\hline & $\Phi A O$ & \multicolumn{5}{|c|}{ 2.1.1,2.1.2,2.3.1,2.3.2,2.4.1,2.5.1,2.5.2, 2.a.1, 2.c.1 (осн); 2.а.2 (доп) } \\
\hline & Росстат & \multicolumn{5}{|c|}{ 2.1.2,2.2.1,2.5.2, Доля домохозяйств, указавших на нехватку денег на еду (2.1) } \\
\hline \multirow[t]{3}{*}{ ЦУР 3} & Задачи & & & 3.4 & & \\
\hline & $\Phi A O$ & \multicolumn{5}{|l|}{-} \\
\hline & Росстат & \multicolumn{5}{|c|}{$\begin{array}{l}\text { Доля граждан, систематически занимающихся физической культурой и спортом (3.4), } \\
\text { Ожидаемая продолжительность здоровой жизни (3.4), Смертность от болезней систе- } \\
\text { мы кровообращения (на } 100 \text { тыс. чел.) (3.4), То же от новообразований, в т.ч. злока- } \\
\text { чественных (3.4), Заболеваемость с установленным впервые в жизни диагнозом рас- } \\
\text { стройств психических и поведения, на } 100 \text { тыс. чел (3.4) }\end{array}$} \\
\hline \multirow[t]{3}{*}{ ЦУР 4} & Задачи & $4.3,4.4$ & & & & \\
\hline & $\Phi А О$ & \multicolumn{5}{|l|}{-} \\
\hline & Росстат & \multicolumn{5}{|c|}{$\begin{array}{l}\text { Валовой коэффициент охвата образовательными программами СПО, \% к численности } \\
\text { населения в возрасте } 15-19 \text { лет (4.3), то же ВО - бакалавриата, специалитета, магистра- } \\
\text { туры, \% от численности населения 17-25 лет (4.3) }\end{array}$} \\
\hline \multirow[t]{3}{*}{ ЦУР 5} & Задачи & $5 b$ & & $5.1,5.5,5 \mathrm{a}$ & & $5 a, 5 b, 5 c$ \\
\hline & $\Phi A О$ & \multicolumn{5}{|c|}{ 5.a.1 (a),5.a.1 (b),5.a.2 (осн) } \\
\hline & Росстат & \multicolumn{5}{|c|}{$\begin{array}{l}\text { 5.5.2,5.5.1.а, Уровень занятости женщин с детьми дошкольного возраста (5c), Числен- } \\
\text { ность прошедших переобучение и повышение квалификации женщин, находящихся в } \\
\text { отпуске по уходу за ребенком в возрасте до трех лет }(5 \mathrm{c})\end{array}$} \\
\hline \multirow[t]{3}{*}{ ЦУР 6} & Задачи & & $6.3,6.4,6.6$ & & & \\
\hline & $\Phi A О$ & \multicolumn{5}{|c|}{$6.4 .1,6.4 .2(\mathrm{ocH})$} \\
\hline & Росстат & \multicolumn{5}{|c|}{$\begin{array}{l}\text { 6.3.1, Площадь восстановленных водных объектов, га (6.6) } \\
\text { Протяженность очищенной прибрежной полосы водных объектов (6.6) }\end{array}$} \\
\hline \multirow[t]{3}{*}{ ЦУР 7} & Задачи & $7.2,7.3$ & $7.2,7.3$ & & & $7.2,7.3$ \\
\hline & $\Phi A$ & \multicolumn{5}{|l|}{-} \\
\hline & Росстат & \multicolumn{5}{|c|}{$\begin{array}{l}\text { 7.3.1, Доля электрической энергии с использованием возобновляемых источников } \\
\text { энергии (ВИЭ), в общем объеме ее производства (7.2), Мощность генерирующих объ- } \\
\text { ектов на основе ВИЭ (без гидроэлектростанций мощностью более } 25 \text { МВт) (7.2) }\end{array}$} \\
\hline \multirow[t]{3}{*}{ ЦУР 8} & Задачи & $8.2,8.8,8.10,8 \mathrm{a}$ & 8.4 & $\begin{array}{l}\text { 8.3,8.5,8.6,8.7, } \\
8.8,8.10,8 b\end{array}$ & & \\
\hline & ФАО & \multicolumn{5}{|l|}{-} \\
\hline & Росстат & \multicolumn{5}{|c|}{$\begin{array}{l}\text { Рост производительности труда на средних и крупных предприятиях базовых несырье- } \\
\text { вых отраслей по отношению к предыдущему году (8.2), То же прирост по отношению к } \\
\text { производительности труда в РФ (8.2), Численность занятых в сфере малого и среднего } \\
\text { предпринимательства (МСП), включая ИП (8.3), Доля МСП в ВВП (8.3), Доля малых ин- } \\
\text { новационно активных предприятий, в числе обследованных, \% (8.3), Доля молодежи, за- } \\
\text { действованной в творческой деятельности, \% (8.3), Потребление топливно-энергетических } \\
\text { ресурсов на одного занятого (8.4), } 8.5 .1,8.6 .1,8.10 .2 \text { Уровень занятости по полу, возрасту } \\
\text { (8.5), Совокупный показатель безработицы и потенциальной рабочей силы по полу, воз- } \\
\text { расту (8.5), Численность пострадавших с утратой трудоспособности на1и более рабочий } \\
\text { день и со смертельным исходом на } 1000 \text { работающих (8.8) }\end{array}$} \\
\hline \multirow[t]{3}{*}{ ЦУР 9} & Задачи & $9.3,9 b, 9 c$ & 9.1 & 9.1 & $9 \mathrm{a}$ & $9.3,9 a, 9 b$ \\
\hline & $\Phi A О$ & \multicolumn{5}{|l|}{-} \\
\hline & Росстат & $\begin{array}{l}\text { Грузооборот п } \\
\text { Плотность же } \\
\text { бильных доро } \\
\text { бильных доро } \\
\% \text { (9.1), То же } \\
\text { автомобильны } \\
\text { бованиям, \% } \\
(9.1), \text { Pейтинг } \\
\text { «Getting credit } \\
\text { широкополосг } \\
\text { значимых объ }\end{array}$ & $\begin{array}{l}\text { о видам транспо } \\
\text { тезнодорожных 1 } \\
\text { общего пользов } \\
\text { г регионального } \\
\text { регионального } \\
\text { х дорог местного } \\
9.1) \text {, Индекс кач } \\
\text { доступности кр } \\
\text { проекта «Doin } \\
\text { екм доступом к } \\
\text { еков инфрастру }\end{array}$ & $\begin{array}{l}\text { млрд. т-км (9.1) } \\
\text { ей общ пользован } \\
\text { я с твердым покр } \\
\text { чения, соответст } \\
\text { межмуниципаль } \\
\text { чения (9.1), То же } \\
\text { a транспортной 1 } \\
\text { тования для мал } \\
\text { siness» Всемирнс } \\
\text { ернет (9.c), то жє } \\
\text { oы (9.c) }\end{array}$ & $\begin{array}{l}\text { о же пассажир } \\
\text { на } 10000 \text { км}^{2} \\
\text { ием на } 1000 \text { км}^{2} \\
\text { ющих норматиı } \\
\text { го значения (9. } \\
\text { рответствующиг } \\
\text { фраструктуры } \\
\text { о и среднего б } \\
\text { банка) }(9.3), \text { Д } \\
\text { рганизаций }(9 . \text { с }\end{array}$ & $\begin{array}{l}\text { zорот, п-км (9.1), } \\
\text { 1), то же автомо- } \\
.1) \text {, Доля автомо- } \\
\text { Iм требованиям, } \\
\text { Протяженность } \\
\text { ормативным тре- } \\
\text { ровню } 2017 \text { года } \\
\text { неса (показатель } \\
\text { д домохозяйств с } \\
\text { то же социально }\end{array}$ \\
\hline
\end{tabular}


Окончание табл. 1

\begin{tabular}{|c|c|c|c|c|c|c|}
\hline \multicolumn{2}{|c|}{ Принципы УР 1} & Принцип 1 & Принцип 2 & Принцип 3 & Принцип 4 & Принцип 5 \\
\hline \multirow{3}{*}{ ЦУР } & Задачи & & & $10.1,10.2,10.3,10.4$ & & $10.2,10.3,10.4$ \\
\hline & ФAО & \multicolumn{5}{|l|}{-} \\
\hline & Росстат & \multicolumn{5}{|c|}{$\begin{array}{l}\text { 10.1.1, Уровень и структура денежных доходов наименее обеспеченных } 40 \% \text { населе- } \\
\text { ния (10.1), Децильный коэффициент дифференциации доходов и коэффициент фон- } \\
\text { дов (10.1), Коэффициент Джини) (10.1), Доля населения с денежными доходами ниже } \\
50 \% \text { медианного эквивалентного денежного дохода }(10.2) \text {, Доля лиц } 15 \text { лет и более, } \\
\text { участвующих в деятельности профсоюзной организации и/или политических партий, } \\
\text { молодежных объединений, женских союзов, обществ инвалидов и/или общественных } \\
\text { советов при органах ГМУ и/или общественных политических, социальных, экологиче- } \\
\text { ских движений в общей численности лиц } 15 \text { лет и более }(10.2)\end{array}$} \\
\hline \multirow{3}{*}{$\begin{array}{l}\text { ЦУР } \\
11\end{array}$} & Задачи & $11.4,11 \mathrm{a}$ & 11.4 & & 11.5 & $11.5,11 \mathrm{a}$ \\
\hline & ФAО & \multicolumn{5}{|l|}{-} \\
\hline & Росстат & \multicolumn{5}{|c|}{$\begin{array}{l}\text { Ассигновано средств на сохранение объектов культурного наследия (11.4), То же (Фак- } \\
\text { тически освоено средств) }(11.4), \text { Кол-во особо охраняемых природных территорий } \\
(\text { ООПТ) федерального значения (11.4), Площадь ООПТ (11.4) }\end{array}$} \\
\hline \multirow[t]{3}{*}{$\begin{array}{l}\text { ЦУР } \\
12\end{array}$} & Задачи & $12.1,12.3$ & $\begin{array}{l}12.2,12.3,12.4 \\
12.5,12.6,12 \mathrm{c}\end{array}$ & 12.5 & & $12.1,12.6$ \\
\hline & $\Phi A O$ & \multicolumn{5}{|l|}{12.3 .1} \\
\hline & Росстат & \multicolumn{5}{|c|}{$\begin{array}{l}\text { Потребление топливно-энергетических ресурсов на одного занятого (12.2), Количе- } \\
\text { ство ликвидированных наиболее опасных объектов накопленного экологического вре- } \\
\text { да (12.4), Доля твердых коммунальных отходов (ТКО), направленных на утилизацию, } \\
\text { в общем объеме ТКО (12.5), Доля ТКО, направленных на обработку, в общем объеме } \\
\text { ТКО (12.5), Доля обезвреженных отходов в общем объеме отходов I и II классов опас- } \\
\text { ности, переданных федеральному оператору (12.5) }\end{array}$} \\
\hline \multirow{3}{*}{$\begin{array}{l}\text { ЦУР } \\
13\end{array}$} & Задачи & 13.3 & & $13.1,13.3$ & $13.1,13.2,13 \mathrm{~b}$ & 13.2 \\
\hline & $\Phi A$ & \multicolumn{5}{|l|}{-} \\
\hline & Росстат & \multicolumn{5}{|c|}{$\begin{array}{l}\text { Общее количество опасных гидрометеорологических явлений (13.2) } \\
\text { Количество отраслевых, региональных и корпоративных планов адаптации к измене- } \\
\text { нию климата (13.2) }\end{array}$} \\
\hline \multirow{3}{*}{$\begin{array}{l}\text { ЦУР } \\
14\end{array}$} & Задачи & $14 \mathrm{~b}$ & $14.1,14.2,14.5$ & $14 \mathrm{~b}$ & $14.5,14 \mathrm{~b}$ & $14.4,14.6,14 \mathrm{c}$ \\
\hline & ФAО & \multicolumn{5}{|c|}{ 14.4.1,14.6.1,14.7.1,14.b.1 (осн); 14.c.1 (доп) } \\
\hline & Росстат & \multicolumn{5}{|c|}{$\begin{array}{l}\text { 14.4.1,14.5.1, Количество морских экспедиций по мониторингу состояния и загрязне- } \\
\text { ния акваторий Мирового океана (14.1) }\end{array}$} \\
\hline \multirow[t]{3}{*}{$\begin{array}{l}\text { ЦУР } \\
15\end{array}$} & Задачи & 15.2 & $\begin{array}{l}15.1,15.2,15.3,15.4 \\
15.5,15.6,15.8,15.9\end{array}$ & & $\begin{array}{l}\text { 15.1,15.3,15.4, } \\
15.5,15.9,15 \mathrm{a} .15 \mathrm{~b}\end{array}$ & $15.9,15 \mathrm{a}, 15 \mathrm{~b}$ \\
\hline & $\Phi A$ & \multicolumn{5}{|c|}{ 15.1.1,15.2.1,15.4.2 (осн); 15.3.1,15.6.1 (доп) } \\
\hline & Росстат & \multicolumn{5}{|c|}{$\begin{array}{l}\text { 15.4.1, Кол-во ООПТ федерального значения (15.1), Отношение площади лесовос- } \\
\text { становления и разведения к площади вырубленных и погибших лесных насаждений } \\
(15.2) \text {, Доля видов млекопитающих в Красной книге РФ, обитающих на ООПТ феде- } \\
\text { рального значения, в общем количестве видов млекопитающих в Красной книге РФ, \% } \\
(15.5) \text {, Индекс объема расходов на сохранение биоразнообразия и ООПТ, \% к преды- } \\
\text { дущему году, (15.a) }\end{array}$} \\
\hline \multirow[t]{3}{*}{$\begin{array}{l}\text { ЦУР } \\
16\end{array}$} & Задачи & & & $16.5,16.6,16.7$ & & $\begin{array}{l}16.3,16.5 \\
16.6,16.7\end{array}$ \\
\hline & $\Phi A O$ & \multicolumn{5}{|l|}{-} \\
\hline & Росстат & \multicolumn{5}{|c|}{$\begin{array}{l}\text { Количество лиц, содержавшихся в СИЗО до окончания предварительного расследования } \\
\text { либо рассмотрения дела судом первой инстанции (16.3), то же доля в общей числен- } \\
\text { ности лиц, содержащихся в СИЗО (\%) (16.3), Общее количество лиц, содержавшихся в } \\
\text { СИЗО (человек) (16.3), Доля предприятий, минимум один раз контактировавших с госу- } \\
\text { дарственным должностным лицом и давших ему взятку или от которых государственные } \\
\text { должностные лица требовали дачи взятки в течение предыдущих } 12 \text { месяцев (16.5) }\end{array}$} \\
\hline \multirow{3}{*}{$\begin{array}{l}\text { ЦУР } \\
17\end{array}$} & Задачи & & & & & $17.1,17.14,17.17$ \\
\hline & ФАО & \multicolumn{5}{|l|}{-} \\
\hline & Росстат & \multicolumn{5}{|c|}{$\begin{array}{l}\text { 17.1.1, ВРП на душу населения (17.1), то же индекс физического объема (17.13), Фак- } \\
\text { тическое конечное потребление домохозяйств на душу (17.13) }\end{array}$} \\
\hline
\end{tabular}

Примечание:

1 - принципы устойчивости АПС, по версии ФАО [16];

2 - цели и задачи устойчивого развития до 2030 года [1];

3 - индикаторы ЦУР в зоне ответственности ФАО [13] и Росстата [20]. 
Как показал анализ методико-аналитического инструментария, наибольшую востребованность ныне имеют публикуемые в рамках реализации Повестки дня в области устойчивого развития до 2030 года информационно-статистические доклады и оценочные разработки ФАО, ЮНИСЕФ, ВОЗ, ЮНЕП, ВПП, МФСР [2, 14, 15, 16, 17, 18]. Кроме того, заслуживающая внимания информация о разработке и внедрении системы показателей для последующих действий и обзора ЦУР-2030 размещена на официальном портале и в серии докладов и публикаций, посвященных обзору хода достижения ЦУР, Статистического отдела Департамента по экономическим и социальным вопросам ООН [21].

Как следует из таблицы, методический подход к обоснованию, оценке и мониторингу ЦУР-2030 основан на трехуровневой иерархической структуре: «цель - задачи индикаторы». В его рамках 17 целей дезагрегированы на 169 задач, качественной и коли- чественной конкретизации которых служит 231 индикатор, представленный в статистически верифицируемом Глобальном перечне показателей Целей в области устойчивого развития, одобренном на 47-й и внесенными изменениями на 51-й сессиях Статистической комиссии ООН по результатам Всеобъемлющего обзора 2020, проведенного Межучрежденческой и экспертной группой по показателям достижения целей в области устойчивого развития (МЭГ-ЦУР) в 2019 году [13, 22, 23].

В зоне непосредственной ответственности ФАО (см. табл. 1) находится 21 индикатор, оценивающий степень достижения ЦУР 2, 5, 6, 12, 14 и 15, а также дополнительных 5 показателей, опосредованно мониторируемых ФАО (табл. 2) [3, 24]. При этом индикаторы, определяющие параметры сбалансированного устойчивого развития АПС в контексте достижения ЦУР $3,4,8,7,9,10,11,13,16,17$, по версии самой же $Ф А О$, этой организацией не отслеживаются.

\section{Таблица 2}

Индикаторы ЦУР в зоне ответственности ФАО, определяющие параметры сбалансированного устойчивого развития АПС [3]

\begin{tabular}{|c|c|c|}
\hline Задачи & & Показатели $^{1}$ \\
\hline \multicolumn{3}{|c|}{ Прямые (в зоне непосредственного мониторинга ФАО) } \\
\hline \multicolumn{3}{|l|}{ ЦУР 2} \\
\hline \multirow{2}{*}{$\begin{array}{l}2.1 \text { К } 2030 \text { году покончить с голодом и } \\
\text { обеспечить всем доступ к безопасной, пи- } \\
\text { тательной и достаточной пище }\end{array}$} & 2.1 .1 & Распространенность недоедания \\
\hline & 2.1 .2 & $\begin{array}{l}\text { Распространенность умеренной или острой нехватки } \\
\text { продовольствия среди населения, на основе Шкалы } \\
\text { оценки продовольственной безопасности (FIES) }\end{array}$ \\
\hline \multirow[t]{2}{*}{$\begin{array}{l}2.3 \text { К } 2030 \text { году удвоить продуктивность } \\
\text { сельского хозяйства и доходы мелких } \\
\text { сельхозпроизводителей }\end{array}$} & 2.3 .1 & $\begin{array}{l}\text { Объем производства на единицу рабочей силы в раз- } \\
\text { бивке по классам сельскохозяйственных / скотоводче- } \\
\text { ских / лесных предприятий }\end{array}$ \\
\hline & 2.3 .2 & $\begin{array}{l}\text { Средний доход мелких производителей продоволь- } \\
\text { ствия в разбивке по полу и статусу коренного насе- } \\
\text { ления }\end{array}$ \\
\hline $\begin{array}{l}2.4 \text { К } 2030 \text { году обеспечить создание } \\
\text { устойчивых систем производства продук- } \\
\text { тов питания }\end{array}$ & 2.4 .1 & $\begin{array}{l}\text { Доля сельскохозяйственных площадей, занятых про- } \\
\text { изводительным и устойчивым сельским хозяйством }\end{array}$ \\
\hline \multirow[t]{2}{*}{$\begin{array}{l}2.5 \text { К } 2020 \text { году обеспечить сохранение } \\
\text { генетического разнообразия семян и куль- } \\
\text { тивируемых растений, домашних и сель- } \\
\text { хоз животных, их диких видов }\end{array}$} & 2.5 .1 & $\begin{array}{l}\text { Количество генетических ресурсов растений и жи- } \\
\text { вотных для производства продовольствия и сельского } \\
\text { хозяйства, находящихся в природоохранных учрежде- } \\
\text { ниях }\end{array}$ \\
\hline & 2.5 .2 & $\begin{array}{l}\text { Доля местных пород, классифицированных как под- } \\
\text { верженные риску, не подверженные риску или неиз- } \\
\text { вестному уровню риска исчезновения }\end{array}$ \\
\hline $\begin{array}{l}\text { 2.а Рост инвестирования, в т.ч. посредством } \\
\text { международного сотрудничества, в сель- } \\
\text { скую инфраструктуру, сельско-хозяйствен- } \\
\text { ные исследования и агропропаганду, раз- } \\
\text { витие технологий и создание генетических } \\
\text { банков растений и животных в целях укре- } \\
\text { пления потенциала сельхозпроизводства }\end{array}$ & 2.a.1 & $\begin{array}{l}\text { Индекс ориентации на сельское хозяйство для госу- } \\
\text { дарственных расходов }\end{array}$ \\
\hline $\begin{array}{l}\text { 2.c Обеспечить функционирование рын- } \\
\text { ков продовольствия с целью ограничения } \\
\text { чрезмерной волатильности цен }\end{array}$ & 2.c.1 & $\begin{array}{l}\text { Индекс ориентации на сельское хозяйство для госу- } \\
\text { дарственных расходов }\end{array}$ \\
\hline
\end{tabular}


Окончание табл. 2

\begin{tabular}{|c|c|c|}
\hline Задачи & & Показатели $^{1}$ \\
\hline \multicolumn{3}{|l|}{ ЦУР 5} \\
\hline \multirow{3}{*}{$\begin{array}{l}\text { 5.а Провести реформы в целях предостав- } \\
\text { ления женщинам равных прав на эконо- } \\
\text { мические ресурсы, а также доступа к вла- } \\
\text { дению и распоряжению землей }\end{array}$} & $\begin{array}{l}5 . a \cdot 1 \\
(a)\end{array}$ & $\begin{array}{l}\text { Доля людей, имеющих право собственности или га- } \\
\text { рантированные права на сельхозземли (от общей чис- } \\
\text { ленности сельского населения), в разбивке по полу }\end{array}$ \\
\hline & \begin{tabular}{|l|}
$5 . \mathrm{a} \cdot 1$ \\
$(\mathrm{~b})$
\end{tabular} & $\begin{array}{l}\text { Доля женщин среди владельцев или правообладате- } \\
\text { лей сельхозземель в разбивке по видам владения }\end{array}$ \\
\hline & $5 . \mathrm{a} .2$ & $\begin{array}{l}\text { Процент стран, в которых правовая база гарантирует } \\
\text { женщинам равные права на владение землей }\end{array}$ \\
\hline \multicolumn{3}{|l|}{ ЦУР 6} \\
\hline \multirow{2}{*}{$\begin{array}{l}6.4 \text { К } 2030 \text { году существенно повысить } \\
\text { эффективность, обеспечить устойчивый } \\
\text { забор и подачу пресной воды }\end{array}$} & 6.4 .1 & Изменение эффективности водопользования во времени \\
\hline & 6.4 .2 & $\begin{array}{l}\text { Уровень нехватки воды: забор пресной воды в про- } \\
\text { порции к имеющимся ресурсам пресной воды }\end{array}$ \\
\hline \multicolumn{3}{|l|}{ ЦУР 12} \\
\hline $\begin{array}{l}12.3 \text { К } 2030 \text { году сократить вдвое количе- } \\
\text { ство пищевых отходов и уменьшить поте- } \\
\text { ри продовольствия }\end{array}$ & 12.3 .1 & $\begin{array}{l}\text { Уровень нехватки воды: забор пресной воды в про- } \\
\text { порции к имеющимся ресурсам пресной воды }\end{array}$ \\
\hline \multicolumn{3}{|l|}{ ЦУР 14} \\
\hline $\begin{array}{l}14.4 \text { К } 2020 \text { году обеспечивать максималь- } \\
\text { ный экологически рациональный рыбный } \\
\text { улов с учетом биологических запасов }\end{array}$ & 14.4 .1 & $\begin{array}{l}\text { Доля рыбных запасов в пределах биологически устой- } \\
\text { чивых уровней }\end{array}$ \\
\hline $\begin{array}{l}\text { 14. } 6 \text { К } 2020 \text { году запретить субсидии, со- } \\
\text { действующие незаконному, нерегулируе- } \\
\text { мому рыбному промыслу }\end{array}$ & 14.6 .1 & $\begin{array}{l}\text { Прогресс стран в осуществлении международных до- } \\
\text { кументов, направленных на борьбу с незаконным, не- } \\
\text { сообщаемым и нерегулируемым рыбным промыслом }\end{array}$ \\
\hline $\begin{array}{l}14.7 \text { К } 2030 \text { году повысить выгоды малых } \\
\text { островных и наименее развитых стран от } \\
\text { рационального использования морских } \\
\text { ресурсов }\end{array}$ & 14.7 .1 & $\begin{array}{l}\text { Устойчивое рыболовство в процентах от ВВП в ма- } \\
\text { лых островных развивающихся государствах, наиме- } \\
\text { нее развитых странах и во всех странах }\end{array}$ \\
\hline $\begin{array}{l}\text { 14.b Обеспечить доступ мелких промыс- } \\
\text { ловых хозяйств к морским ресурсам и } \\
\text { рынкам }\end{array}$ & 14.b.1 & $\begin{array}{l}\text { Прогресс стран во внедрении правовой/ политиче- } \\
\text { ской/ институциональной основы, которая защищает } \\
\text { права доступа для мелкомасштабного рыболовства }\end{array}$ \\
\hline \multicolumn{3}{|l|}{ ЦУР 15} \\
\hline $\begin{array}{l}15.1 \text { К } 2020 \text { году обеспечить рациональ- } \\
\text { ное использование наземных и пресно- } \\
\text { водных экосистем }\end{array}$ & 15.1 .1 & Площадь лесов в проценл \\
\hline $\begin{array}{l}15.2 \text { К } 2020 \text { году содействовать внедре- } \\
\text { нию методов рационального использова- } \\
\text { ния лесов }\end{array}$ & 15.2 .1 & Прогресс в области устойчивого лес \\
\hline $\begin{array}{l}15.4 \text { К } 2030 \text { году обеспечить сохранение } \\
\text { горных экосистем }\end{array}$ & 15.4 .2 & Индекс зеленого покрова горных районов \\
\hline \multicolumn{3}{|c|}{ Косвенные (опосредованный мониторинг ФАО) } \\
\hline $\begin{array}{l}1.4 \text { К } 2030 \text { году обеспечить равные права } \\
\text { мужчин и женщин, малоимущих и уязви- } \\
\text { мых, на экономические ресурсы, в т.ч. до- } \\
\text { ступ к земле }\end{array}$ & 1.4 .2 & $\begin{array}{l}\text { Доля взрослого населения, имеющего гарантирован- } \\
\text { ные права владения землей, с юридически признанны- } \\
\text { ми документами и считаюеег свои права на землю га- } \\
\text { рантированными, в разбивке по полу и типу владения } \\
\end{array}$ \\
\hline $\begin{array}{l}1.5 \text { К } 2030 \text { году повысить жизнестойкость } \\
\text { малоимущих и уязвимых лиц перед по- } \\
\text { трясениями и бедствиями }\end{array}$ & 1.5 .2 & $\begin{array}{l}\text { Прямые экономические потери от стихийных бед- } \\
\text { ствий по отношению к мировому валовому внутрен- } \\
\text { нему продукту (ВВП) }\end{array}$ \\
\hline 2.а см. выше & 2.a.2 & $\begin{array}{l}\text { Общий объем официальных потоков (официальная } \\
\text { помощь в целях развития плюс другие официальные } \\
\text { потоки) в сельскохозяйственный сектор }\end{array}$ \\
\hline $\begin{array}{l}\text { 14.с Улучшить работу по сохранению и } \\
\text { рациональному использованию океанов и } \\
\text { их ресурсов }\end{array}$ & 14.c. 1 & $\begin{array}{l}\text { Число стран, добивающихся прогресса в ратификации, } \\
\text { принятии документов в целях сохранения и устойчиво- } \\
\text { го использования мирового океана и его ресурсов }\end{array}$ \\
\hline $\begin{array}{l}15.3 \text { К } 2030 \text { году вести борьбу с опустынива- } \\
\text { нием, восстановить деградировавшие земли }\end{array}$ & 15.3 .1 & Доля деградированных земель в общей площади земель \\
\hline $\begin{array}{l}15.6 \text { Содействовать справедливому распре- } \\
\text { делению благ от генетических ресурсов }\end{array}$ & 15.6 .1 & $\begin{array}{l}\text { Число стран, которые приняли законодательные, ад- } \\
\text { министративные и политические рамки для справед- } \\
\text { ливого и равноправного распределения выгод }\end{array}$ \\
\hline
\end{tabular}

Примечание:

${ }^{1}$ нумерация и наименование в соответствие с Система глобальных показателей достижения целей в области устойчивого развития и выполнения задач Повестки дня в области устойчивого развития на период до 2030 года A/RES/71/313 E/CN.3/2018/2 
На национальном уровне существенный объем работ по методическому обеспечению и статистической верификации ЦУР2030 ведет Федеральная служба государственной статистики РФ, на которую Распоряжением Правительства РФ от 6 июня 2017 года № 1170-р возложены полномочия по формированию и представлению в международные организации официальной статистической информации по показателям достижения ЦУР, а также координация работ по обеспечению их мониторинга в составе Межведомственной рабочей группы при Администрации Президента РФ по вопросам изменения климата и устойчивого развития $[25,26]$.

В целях информационного обеспечения процесса мониторинга ЦУР на национальном уровне в 2017 году на веб-портале Росстата создан раздел «Цели устойчивого развития» (https://rosstat.gov.ru/sdg), где размещен подробный перечень и метаданные показателей ЦУР с актуальным статусом их разработки, ссылками на полезные ресурсы и документы, а также с регулярным обновлением данных в Единой межведомственной информационно-статистической системе (ЕМИСС) по адресу: https://fedstat. $\mathrm{ru} /$ в подразделе 2.8. «Показатели достижения целей устойчивого развития Российской Федерации».

Российский перечень из 160 актуальных на текущей период показателей достижения ЦУР, часть из которых представлена в таблице, сформирован в соответствии с резолюцией Генеральной Ассамблеи $\mathrm{OOH} \mathrm{A} /$ RES/71/313 по разработке национальных наборов показателей ЦУР, с учетом национальных приоритетов в соответствие с Указами Президента РФ от 07.05.2018 № 204, от 21.07.2020 № 474, целеполагания документов стратегического планирования и национальных проектов, статистического потенциала [20].

Как следует из таблицы, национальный набор показателей достижения ЦУР не только существенно шире Глобального перечня индикаторов (имеют трехкомпонентную цифровую индексацию - прим. авторов), но и в отличие от мониторируемых ФАО, ориентированы на оценку всех 17-ти ЦУР.

Между тем ни глобальные, ни, тем более, национальные показатели не позволяют вычленить специфику аграрной экономики, масштабы ее воздействия на экологические системы, уровень социального благопо- лучия сельских населения и территорий. Этим не обеспечивается ни сбалансированность системы статистических показателей ЦУР, ни оценочный инструментарий в контексте устойчивости АПС, в том числе национальной.

С учетом подобных критических замечаний и специфики функционирования АПС России полагаем целесообразным указать на следующие принципиальные положения:

- в целях межстрановых и межрегиональных сопоставлений желательно большинство показателей приводить или к единице стоимости $\mathrm{BB}(\mathrm{H}) П / В Р П$, или на душу населения. По всей видимости, более корректными являются среднедушевые показатели. На этот счёт убедительный пример демонстрирует межстрановый анализ по паритету покупательной способности удельной энергоёмкости ВВП, свидетельствующий, что в развитой экономике США этот показатель выше, чем в развивающихся странах, например, Кубе - в 1,9, Чили - 1,37, Перу 2,37 , Индии - 1,37, Бангладеш - 2,11, Турции $-1,58$ раз. Подобные сравнения в пользу энергоэффективности развивающихся экономик по сравнению с развитыми указывают на явную некорректность упрощенных макроэкономических сопоставлений [27];

- в случае расчета интегральных индикаторов, среднегеометрический способ агрегирования показателей более предпочтителен по сравнению со среднеарифметическим, что позволяет нивелировать «эффект замещаемости измерений», когда низкие значения одних показателей компенсируются высокими значениями других;

- необходимость учета в глобальных измерениях страновой, в отечественной аналитике региональной специфики, иначе разработка специфических показателей. Например, для южных регионов России с ярко выраженной сельскохозяйственной, и более этого, растениеводческой специализацией, устойчивость региональных АПС во многом определяется состоянием почвенно-земельных ресурсов, полагая важным в расчете показателей учитывать ущерб от деградации сельскохозяйственных земель, равно, как в условиях дефицитности водных, лесных ресурсов - количественные параметры их сбережения и воспроизводства;

- наконец, важность мониторирования статистических показателей достижения ЦУР в разрезе собственно сельского хозяйства и смежных с ним отраслей, а так- 
же сельских территорий, тем более подобная информационная база по адресу https:// rosstat.gov.ru/storage/mediabank/sel_terr.html формируется Росстатом с 2014 года на основе статистических и административных данных администраций муниципальных образований по форме № 1-МО «Сведения об объектах инфраструктуры муниципального образования». Подобная избирательность крайне необходима в межсекторальном анализе, в сравнении с урбанизированными территориями и средними показателями в стране.

Следуя рекомендациям авторитетного документа [1], а также с учетом высказанных замечаний полагаем целесообразным сбалансированную систему оценочных показателей ЦУР в контексте устойчивости национальной АПС вести по совокупности показателей, имеющих систематическую актуализацию и статистическую верификацию:

- показатели социальной компоненты, следуя ЦУР $1,2,3,4,5,16$, должны количественно отражать проблемы сельской бедности и неравенства, обеспечения сельского населения продовольствием, социальной инфраструктурой, условия для сельского развития и занятости, особенно среди женщин и молодежи. Важным является характеристика параметров здоровья сельского населения и качественного обеспечения медицинскими услугами, доступность многоуровневого образования, обеспечение гендерного равенства;

- показатели экономической компоненты, отражая ЦУР 8,9,10,12,17, должны количественно характеризовать параметры развития аграрной экономики, продовольственного обеспечения, обеспечения полной и производительной сельской занятости, инфраструктурную развитость сельских территорий, содействие всемерной и устойчивой агроиндустриализации и агроинновациям, охватывать проблематику сокращения неравенства в доходах селян по сравнению с городским населением, перехода к рациональным моделям потребления и производства, а также количественные показатели включенности национального аграрного сектора в мирохозяйственные связи;

- показатели, характеризующие экологическую компоненту ЦУР 6,7,11,13, 14,15, следует ориентировать на параметры качества и рационального использования водных ресурсов в аграрной отрасли, доступ сельского населения к источникам энергии, экологические параметры сельских населенных пунктов, адаптацию аграрной отрасли к климатическим флуктуациям и природным стихийным бедствиям, репродукцию, долговременную продуктивность, рациональное использование экосистем морей, суши, земельных, лесных, биологических ресурсов, подверженных воздействию агарного производства.

\section{Выводы}

По результатам предпринятого исследования авторами сформулированы следующие выводы и предложения:

1) показано, что методический подход ФАО, Статистической комиссии ООН, Статистического отдела ООН, Федеральной службы государственной статистики РФ к обоснованию, оценке и мониторингу ЦУР-2030 основан на трехуровневой иерархической структуре: «цель - задачи - индикаторы», включающей 17 целей, 169 задач, 231 индикатор в Глобальном перечне и 160 - в Российском наборе показателей. В зоне непосредственной ответственности ФАО находится 21 индикатор, оценивающий степень достижения ЦУР 2, $5,6,12,14$ и 15 , а также дополнительных 5 показателей, опосредованно мониторируемых ФАО. Выявлено, что ни глобальные, ни национальные показатели достижения ЦУР-2030 не позволяют вычленить специфику аграрной экономики, масштабы ее воздействия на экологические системы, уровень социального благополучия сельских населения и территорий.

2) в рамках методологического ключа, основанного на принципах ФАО и авторского подхода к устойчивости национальной АПС, с использованием методических разработок и оценочного инструментария ФАО, Статистической комиссии ООН, Статистического отдела ООН, Федеральной службы государственной статистики РФ обоснована сбалансированная система оценочных показателей ЦУР в контексте устойчивости национальной АПС, основанная на совокупности систематически мониторируемых и статистически верифицируемых количественных индикаторов в разрезе собственно сельского хозяйства, смежных с ним отраслей, сельских населения и территорий, позволяющая вести сравнительный анализ в разрезе стран, регионов, сопоставление с урбанизированными территориями и средними показателями в стране. 
3) предложено в контексте оценки устойчивости национальной АПС связать показатели социальной компоненты (ЦУР $1,2,3,4,5,16)$ с сокращением сельской бедности и неравенства, обеспечением сельского населения продовольствием и социальной инфраструктурой, условиями для сельского развития, параметрами здоровья сельского населения и качества медицинских услуг, доступностью многоуровневого образования; экономической (ЦУР $8,9,10,12,17$ ) - с развитием аграрной экономики, продовольственным обеспечением, сельской занятостью, инфраструктурой сельских территорий, агро- индустриализацией и инновациям, переходом к рациональным моделям потребления и производства, включенностью национального аграрного сектора в мирохозяйственные связи; экологической (ЦУР $6,7,11,13,14,15)$ - со сбережением и обеспеченностью водой, энергией сельской местности и аграрной отрасли, адаптацией сельского хозяйства к климатическим и природным рискам, репродукцией, долговременной продуктивностью, рациональным использованием природных ресурсов в агарном производстве и качеством среды в сельской местности.

В целом материалы исследования убедительно демонстрируют, что экономическая политика и хозяйственная практика устойчивого развития АПС предполагают наличие сбалансированного оценочного инструментария, позволяющего не только тестировать качественные и количественные параметры состояния и динамики АПС, но, что не менее важно, служить адекватным национальной проблематике и глобальным тенденциям ориентиром для управленческих и бизнес решений, а также индикатором результативности и эффективности предпринимаемых инициатив.

Исследование выполнено при финансовой поддерэнке РФФИ в рамках научного проекта № 20-010-00375 «Методология формирования и разработки организационно-экономического механизма достижения целей устойчивого развития в национальной агропродовольственной системе»

\section{Библиографический список}

1. Преобразование нашего мира: Повестка дня в области устойчивого развития на период до 2030 года. Резолюция, принятая Генеральной Ассамблеей 25.09.2015 года A/RES/70/1 [Электронный ресypc]. URL: http://docs.cntd.ru/document/420355765 (дата обращения: 08.11.2021).

2. The State of Food Security and Nutrition in the World 2020. Transforming food systems for affordable healthy diets. Rome, Italy: WHO, IFAD, WFP, UNICEF. 2020. 320 p.

3. Transforming food and agriculture to achieve the SDGs 20 interconnected actions to guide decisionmakers. Rome: Food and agriculture organization of the united nations, 2018. [Электронный ресурс]. URL: https://www.fao.org/3/I9900EN/i9900en.pdf.

4. Fischer G. Transforming the global food system // Nature. 2018. Vol. 562 (7728). P. 501-502.

5. Siebrecht N. Sustainable Agriculture and Its Implementation Gap - Overcoming Obstacles to Implementation // Sustainability. 2020. № 12. P. 3853.

6. Lampridi M.G., Sørensen C.G., Bochtis D. Agricultural Sustainability: A Review of Concepts and Methods // Sustainability. 2019. № 11. P. 5120.

7. Valentini R., Sievenpiper J., Antonelli M., Dembska K. Achieving the Sustainable Development Goals Through Sustainable Food Systems. Springer, Cham. 2019. DOI: 10.1007/978-3-030-23969-5.

8. Allen C., Metternicht G., Wiedmann T. Initial progress in implementing the Sustainable Development Goals (SDGs): a review of evidence from countries // Sustainability Science. 2018. Vol. 13. № 5. P. 1453-1467.

9. Белоусов В.М. Обоснование системы целей устойчивого развития аграрного сектора экономики // Агропродовольственная политика России. 2017. № 1. С. 27-32.

10. Нечаев В.И., Васильева Н.К., Фетисов С.Д. Оценка устойчивости развития аграрного сектора // Экономика сельского хозяйства России. 2010. № 2. С. 27-34.

11. Пастухова Н.Ю., Емельянова Е.В. Основные индикаторы устойчивого развития агропромышленного комплекса ДФО // Селекция, семеноводство и технология плодово-ягодных культур и картофеля: сборник научных трудов. Челябинск, 2021. С. 164-172. 
12. Чередниченко О.А., Довготько Н.А., Яшалова Н.Н. Устойчивое развитие агропродовольственного сектора: российские приоритеты и направления адаптации Повестки дня - 2030 // Экономические и социальные перемены: факты, тенденции, прогноз. 2018. Т. 11. № 6. С. 89-108.

13. Система глобальных показателей достижения целей в области устойчивого развития и выполнения задач Повестки дня в области устойчивого развития на период до 2030 года. A/RES/71/313 E/CN.3/2018/2

14. Положение дел в области продовольственной безопасности и питания в мире -2019 . Меры защиты от замедления роста экономики и экономических спадов. Рим: ФАО, МФСР, ЮНИСЕФ, ВПП и ВОЗ, 2019. $214 \mathrm{c}$.

15. Сельское хозяйство и Повестка дня в области устойчивого развития на период до 2030 года, 25-я сессия ФАО, Рим, 26-30 сентября 2016 года COAG/2016/4 [Электронный ресурc]. URL: http://www. fao.org/3/a-mr022r.pdf.

16. Building a common vision for sustainable food and agriculture - Principles and approaches food and agriculture organization of the united nations. Rome. 2014 [Электронный ресурc]. URL: http://www.fao.org/3/ai3940e.pdf.

17. The State of Food Security and Nutrition in the World 2019. Safeguarding against economic slowdowns and downturns. Rome, Italy: FAO, WHO, IFAD, WFP, UNICEF. 2019 [Электронный ресурc]. URL: www.fao. org/3/ca5162en/ca5162en.pdf.

18. Программа ЮНЕП по устойчивым продовольственным системам [Электронный ресурс]. URL: https://www.unenvironment.org/explore-topics/resource-efficiency/what-we-do/sustainable-lifestyles/ food-and-food-waste.

19. Медяник Н.В., Чередниченко О.А., Довготько Н.А., Рыбасова Ю.В. Комплексная оценка национальной агропродовольственной системы в контексте устойчивого развития // Международный сельскохозяйственный журнал. 2020. № 6 (378). С. 15-19.

20. Национальный набор показателей ЦУР [Электронный ресурс]. URL: https://rosstat.gov.ru/storage/ mediabank_data.xlsx.

21. The Sustainable Development Goals Progress Chart 2019 [Электронный pecypc]. URL: https://unstats. un.org/sdgs/report/2019/progress-chart.pdf.

22. Статистическая комиссия Сорок седьмая сессия 8-11 марта 2016 года Пункт 3(а) предварительной повестки дня. Вопросы для обсуждения и принятия решения: данные и показатели для Повестки дня в области устойчивого развития на период до 2030 года E/CN.3/2016/2/Rev.1.

23. Статистическая комиссия. Пятьдесят первая сессия 3-6 марта 2020 года Пункт 3 а) предварительной повестки дня. Вопросы для обсуждения и принятия решения: данные и показатели для Повестки дня в области устойчивого развития на период до 2030 года Е/CN.3/2020/3.

24. Цели в области устойчивого развития. Отслеживание прогресса [Электронный ресурс]. URL: https://www.fao.org/sustainable-development-goals/tracking-progress/ru.

25. Добровольный национальный обзор достижения Российской Федерацией Целей устойчивого развития (ЦУР) и реализации Повестки в области устойчивого развития на период до 2030 года [Электронный ресурc]. URL: https://sustainabledevelopment.un.org/ index.php?page=view\&type=30022\&nr=1686\&me $\mathrm{nu}=3170$.

26. Цели устойчивого развития в Российской Федерации. 2020: Крат. стат. сб. / Росстат. М., 2020. 79 с.

27. Безруких П.П. Энергоэффективность охраны окружающей среды: актуальные задачи // Бюллетень «На пути к устойчивому развитию России». 2012. № 61. С. 39-49. 